\title{
Does Jatropha curcas L. show resistance to drought in the Sahelian zone of West Africa? A case study from Burkina Faso
}

\author{
P. Bayen ${ }^{1}$, T. K. Sop ${ }^{2}$, A. M. Lykke ${ }^{3}$, and A. Thiombiano ${ }^{1}$ \\ ${ }^{1}$ Laboratory of Plant Biology and Ecology, University of Ouagadougou, 09 BP 848, Ouagadougou 09, Burkina Faso \\ ${ }^{2}$ Research Unit of Biodiversity, Evolution and Ecology of Plants, Biocentre Klein Flottbek, University of Hamburg, \\ Hamburg, Germany \\ ${ }^{3}$ Department of Bioscience, Aarhus University, Aarhus, Denmark \\ Correspondence to: P. Bayen (phbayen@yahoo.fr)
}

Received: 5 January 2015 - Published in Solid Earth Discuss.: 10 February 2015

Revised: 22 April 2015 - Accepted: 23 April 2015 - Published: 21 May 2015

\begin{abstract}
Land degradation is an environmental problem which weakens agro-sylvo-pastoral productivity in subSaharan Africa. The most common manifestation of land degradation is the appearance of denuded land. We carried out an experiment to test the effect of three soil and water conservation techniques on survival and growth of Jatropha curcas seedlings transplanted onto two completely denuded lands in the Sahelian and Sudanian zones of Burkina Faso. We implemented an experimental design with three replicates per restoration technique. A total of 174 seedlings were planted in each study site. The results showed that the soil water content varied according to the restoration technique used ( $\mathrm{df}=2 ; F=53.21 ; p<0.00)$ as well as according to study site $(\mathrm{df}=1 ; F=74.48 ; p<0.00)$. Soil water content was significantly lower in the Sahel than in the Sudanian zone. Seedling survival rate varied significantly according to technique used $(\mathrm{df}=2 ; F=8.91 ; p=0.000)$ and study site $(\mathrm{df}=1 ; F=9.74 ; p=0.003)$. Survival rate, diameter and seedling height were highest at the Sudanian site. At the Sahelian site, all seedlings died 2 years after establishment. These results suggest that $J$. curcas is unsuited to denuded land in the Sahelian zone. Most of the plants died in the Sahel between April and May, which is the peak of the dry season; this may be an indication that $J$. curcas may not be as drought-resistant as suggested by the prolific literature which has reported on diverse claims surrounding this plant.
\end{abstract}

\section{Introduction}

Land degradation is a global environmental problem threatening the survival of more than 250 million people in the arid lands of developing countries and jeopardizing sustainable development (Sop et al., 2012; Fleskens et al., 2014). In the Sudano-Sahelian region of west Africa, the combined effects of drought, poor soil quality and human impact have resulted in soil degradation due to crusting, sealing and erosion by water and wind (Mando et al., 1999). Drought and soil characteristics interact to affect seedling mortality (MartínezGarza et al., 2013), provoking a strong negative impact on biodiversity (Bisaro et al., 2014) and on agro-silvo-pastoral production (Sidibé, 2005). The low vegetation cover as a consequence of prolonged drought and grazing pressure, in conjunction with the soil water repellency, induces high runoff rates (Cerda et al., 1998).

In Burkina Faso, one of the most common manifestations of land degradation is the appearance of the "zippelés", which, in the local Mooré language, refers to barren, encrusted whitish soil surfaces which have become useless to local people for agro-silvo-pastoral activities (Sop et al., 2012).

The actions to combat land degradation generally consist of mitigation and restoration interventions (Zucca et al., 2013). The latter often involve the improvement of vegetation cover through, for example, the (re)introduction of adapted species, the control of invasive species and reforestation (Zucca et al., 2014). Planting trees in degraded lands can stabilize soils, mitigate erosion and increase fertility (Fisher, 
1995; Barua et al., 2013) as well as increasing understory biodiversity (Parrotta, 1992; Gilardelli et al., 2013). Acacia spp species have always been the most valued plants for reforestation of degraded areas in Sahelian countries due to their renowned capacity to resist drought and extreme climatic conditions. But in the recent years, the rise of the prices of fossil energy in Burkina Faso and the evidence that $\mathrm{CO}_{2}$ pollution is the main driver of climate change have attracted the attention of decision-makers, project managers and farmers to Jatropha curcas L., which is believed to be able to provide social, environmental and economic benefits to the poor rural communities in west Africa. The plant has attained increasing interest for biofuel and improved income of farmers (Meng et al., 2009).

Jatropha curcas L. (J. curcas) is a multipurpose shrub or small tree belonging to the family of Euphorbiaceae with many attributes and multiple uses.

The plant is said to be well adapted to marginal soils with low nutrient levels and to be able to survive in very poor, dry soil conditions considered unsuitable for agriculture (Achten et al., 2008). The planting of J. curcas can therefore be considered as an effective option for rehabilitating wastelands and improving employment opportunities and livelihoods in rural areas (Achten et al., 2010b). Considering all the alleged advantages, the cultivation of the biofuel crop J. curcas L. in Burkina Faso may contribute to the amelioration of the soil fertility of severely declining cropland through increased organic matter input and erosion control (Baumert et al., 2014). Recent research has confirmed that J. curcas can indeed thrive in arid conditions due to its drought-avoidance strategy (Rao et al., 2012).

Several studies have investigated the performance of $J$. curcas in terms of biomass production (Bayen et al., 2015), water conservation and drought tolerance under arid conditions (Maes et al., 2009; Achten et al., 2010a). Little research, however, has focused on the ability of J. curcas to grow in the marginal soils of the Sahel (Kagambèga et al., 2011a; Sop et al., 2012). Hence, a gap in our knowledge exists regarding the capacity for adaptation and the growth response of $J$. curcas under Sahelian conditions. If it is possible to convert the barren and unproductive soils of the Sahelian and Sudanian zones of Burkina Faso into productive ones by growing J. curcas, it would strengthen local livelihoods and increase their income diversification, at the same time reducing carbon emissions by producing biofuels. Under the constraints of the Sahelian environment, however, it is necessary to put into place soil and water conservation techniques in order to ensure the productivity of such barren soils. These techniques include soil restoration methods such as half-moon, sub-soiling furrows in soil and the zaii (traditional technique used in the Sahel zone for the restoration of degraded and crusted soils) technique (Zougmoré et al., 2003; Ganaba, 2005), all of which have been shown to be efficient in increasing soil water content. The aim of the current study is to evaluate the efficiency of several soil restoration techniques

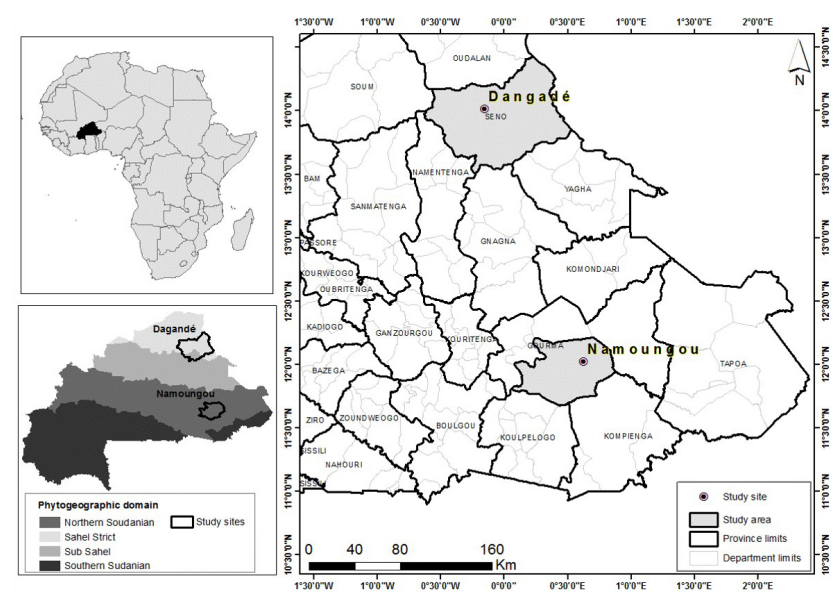

Figure 1. Phytogeographic domains and geographic locations of the experimental sites.

in the growth performance of $J$. curcas on completely barren and denuded soil in two agro-ecological zones in Burkina Faso. More specifically, the research assesses the effect of different treatments on soil moisture content, and it evaluates the survival and growth performance of $J$. curcas under three soil and water conditions (half-moon, zaï and standard plantation). Our overall goal is to contribute to a better understanding of the ability of $J$. curcas to adapt to harsh climatic environments.

\section{Material and methods}

\subsection{Study areas}

The study sites are located at Namoungou $\left(0^{\circ} 36^{\prime} 53.34^{\prime \prime} \mathrm{E}\right.$ and $12^{\circ} 2^{\prime} 19.55^{\prime \prime} \mathrm{N}$ ) in the north Sudanian zone and at Dangadé $\left(0^{\circ} 9^{\prime} 33.04^{\prime \prime} \mathrm{W}\right.$ and $\left.14^{\circ} 0^{\prime} 31.52^{\prime \prime} \mathrm{N}\right)$ in the Sahel (Fig. 1). Phytogeographically, Burkina Faso is divided into a Sahelian and a Sudanian domain, separated by the 13th parallel $\left(13^{\circ} \mathrm{N}\right)$. The ecological conditions differ between the two areas. The climate in Namoungou is characterized by a short rainy season lasting from May to September and a long dry season from October to April. The mean annual rainfall over the last 30 years is $822 \mathrm{~mm}$, while mean temperatures for the same period reached $28^{\circ} \mathrm{C}$.

In Dangadé, the rainy season lasts from July to September and the dry season from October to June. Rainfall is characterized by an irregular distribution, with a mean precipitation of $467 \mathrm{~mm} \mathrm{yr}^{-1}$, of which about $90 \%$ falls between July and August. The mean annual rainfall over the last 30 years is $467 \mathrm{~mm}$, while mean temperatures for the same period reached $29^{\circ} \mathrm{C}$ (Fig. 2). 


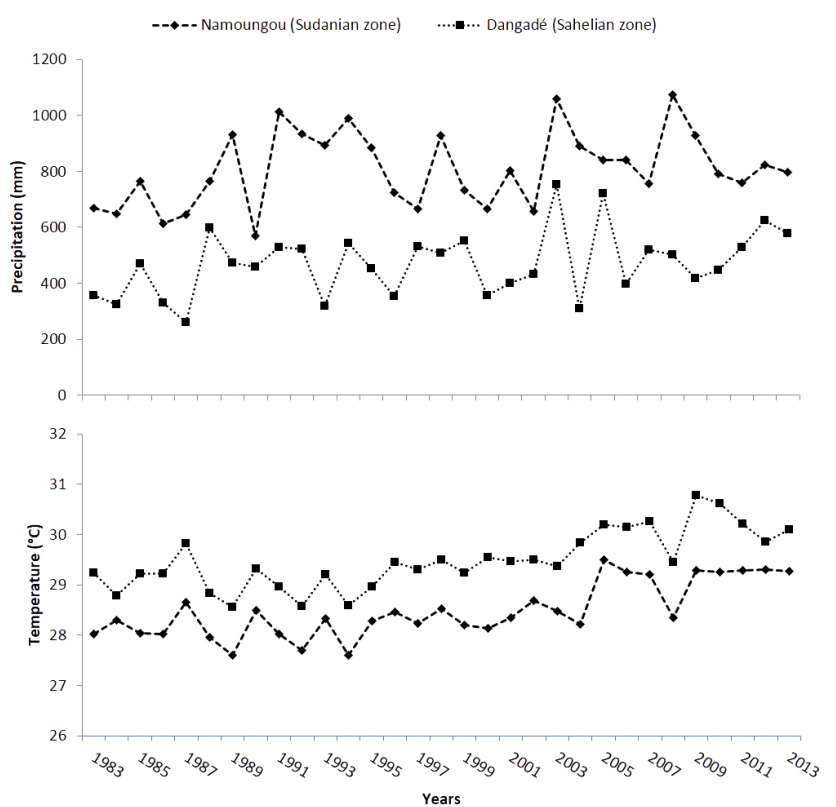

Figure 2. Mean rainfall $(\mathrm{mm})$ and mean temperatures record $\left({ }^{\circ} \mathrm{C}\right)$ for the weather station of Dori (Sahelian zone) and Fada N'Gourma (Sudanian zone), near the experimental sites, between 1983 and 2013.

\subsection{Restoration techniques}

Three restoration techniques were tested: half-moon, zaï and standard plantation (Fig. 3).

The half-moon technique is designed to collect surface runoff by excavation of holes on bare and crusted soils with gentle slopes (Zougmoré et al., 2003). In this study, the halfmoons were $2 \mathrm{~m}$ in diameter, spaced out by $1 \mathrm{~m}$ in rows approximately $3 \mathrm{~m}$ apart. In each half-moon the water collection area was $3.14 \mathrm{~m}^{2}$. The area between the half-moons served as the impluvium (the non-cultivated area between half-moons which is used to collect runoff water). The holes, $10-15 \mathrm{~cm}$ depth, were dug with a hoe or a pick in order to break through the crusted layer on the soil surface and to collect the runoff water. Excavated earth served to form ridges around the edges of the half-moons.

The zaï is a traditional technique that has been used for centuries in the Sahel zone for the restoration of degraded and crusted soils. The zaii technique involves manually digging holes to collect surface runoff (Roose et al., 1999). In this study, the zaï holes were about $20 \mathrm{~cm}$ in diameter, $15 \mathrm{~cm}$ deep and separated by $3 \mathrm{~m}$. The excavated soil served to form ridges around the holes. No organic material was used in this experiment.

The standard plantation technique consists of planting seedlings from the nursery in pits prepared with a hoe or a pick. In this study, the holes were $40 \mathrm{~cm}$ in diameter, $40 \mathrm{~cm}$ deep and $3 \mathrm{~m}$ apart. The excavated soil served to form a pile of ground around the holes.

\subsection{Plantation}

In August 2011, 3-month-old nursery-raised seedlings were planted in plots in the two study sites using a randomized design with three treatments each with three replicates: (i) HM: half-moon technique; (ii) SP: standard plantation; and (iii) zaï: zaï technique.

A total of 174 seedlings were planted at each study site. In total, we placed nine plots in each study site. In each plot $(14 \mathrm{~m} \times 11 \mathrm{~m}$ in size), 20 seedlings each were planted using the zaï and standard plantation techniques, and 18 seedlings were planted using the half-moon technique. Fertilizer was not applied during refilling of the pits, and the plants were not watered.

\subsection{Data collection}

\subsubsection{Assessment of soil water content}

We measured soil moisture gravimetrically for each of the restoration techniques in October 2012, during the dry season, at five different depths: 0-10, 10-20, 20-30, 30-40 and $40-50 \mathrm{~cm}$. Three measures, one per replicated block and period, were taken at each depth level, corresponding to a total of 45 measures for each year. For each depth level, three soil samples were stored in sealed boxes. Samples were ovendried at $105^{\circ} \mathrm{C}$ to enable us to determine constant measurements of weight and water content.

\subsubsection{Seedling performance}

For each plot, plant height (i.e., the height of the apical meristem above the ground surface) and diameter (i.e., stem diameter at the ground surface) were measured monthly for 4 months (from December 2011 to April 2014). In September 2011, i.e., 1 month after the seedlings were planted, we assessed the transplantation losses (i.e., seedling mortality due to the transfer of seedlings from the nursery to the plot). Survival rates were recorded again in December 2011; April, August and December 2012 and 2013; and April 2014.

\subsubsection{Statistical analysis}

We computed the effects of the independent factors (treatments and sites) on the growth parameters (survival rate, height and diameter) of the seedlings with repeated ANOVA measures, using the JMP 9 program (SAS Institute, 2010). We checked for normality and homogeneity of variance using, respectively, the Shapiro-Wilk test of normality and the Levene test for the homogeneity of variances. Data on survival rate were transformed to ensure normality. The effect of treatment on soil moisture content was performed on the measuring values. Variables with significant differences were compared using Tukey's HSD test at the $5 \%$ level. 


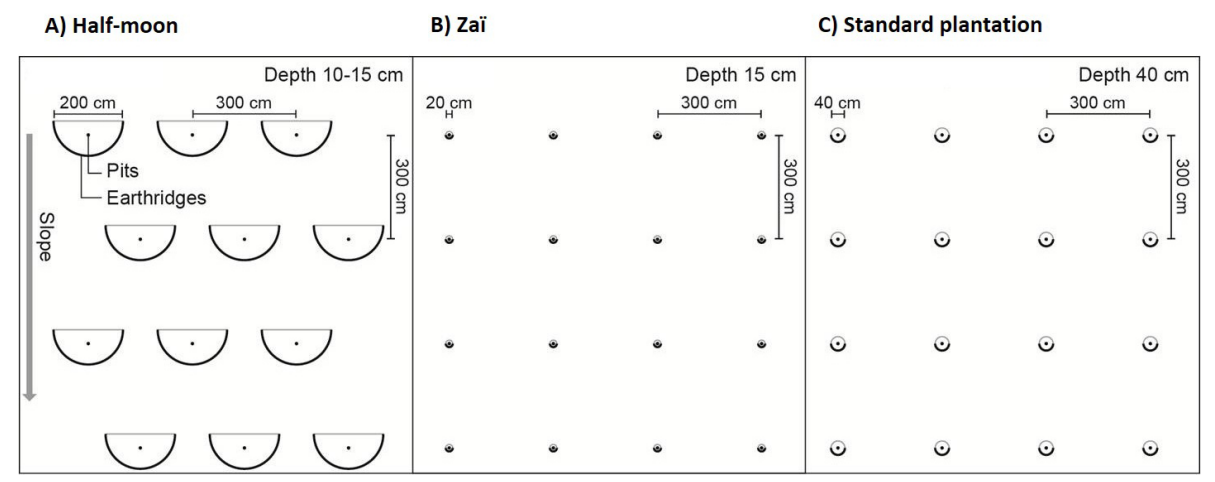

Figure 3. Specifications of restoration techniques.
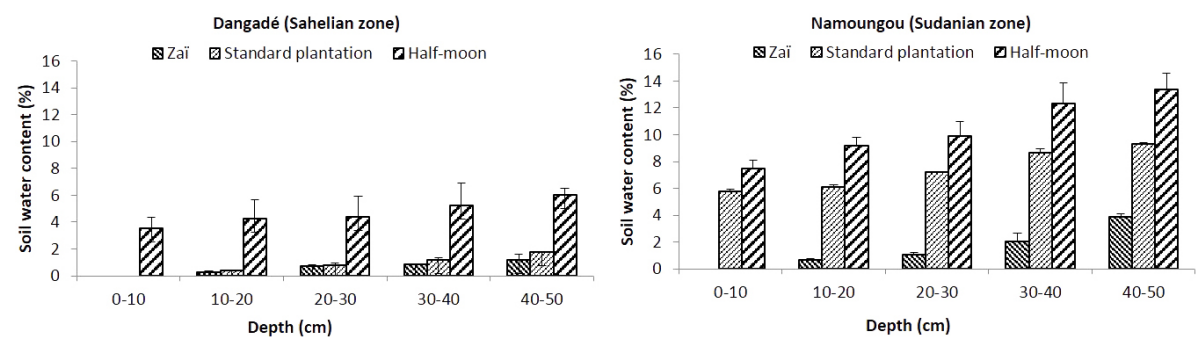

Figure 4. Effect of treatments on soil water content at different depth levels in October 2012 (error bars show the standard deviation).

\section{Results and discussion}

\subsection{Effect of treatment on soil moisture content}

Soil water content (SWC) varied significantly between the restoration techniques $(\mathrm{df}=2 ; F=53.21 ; p<0.00)$ but did not vary between depth levels $(\mathrm{df}=4 ; F=0.70 ; p=0.59)$. SWC was higher under the half-moon technique and lower under the zaï (Fig. 4). Denuded soils are well known to be characterized by their poor degree of permeability and their low water-storage capacity. The hard outer crust that forms on these soils results in poor water infiltration and ventilation of the horizontal layers (Bayen et al., 2011). Consequently, where there is low rainfall, the seedlings cannot obtain enough water to meet their growth requirements.

Destroying the surface crust by stripping away the surface horizon temporarily improved soil porosity and hence infiltrability (Casenave and Valentin, 1992). A likely reason for our finding that SWC was higher in the plots treated with the half-moon technique than those treated with zaï and standard plantation techniques is that half-moon plots had larger impluvia, causing water to infiltrate the soil more deeply. These results are in accordance with those found by Kagambèga et al. (2011a) in the same study area. Indeed, the most effective way to increase soil productivity in the sub-Saharan zone is to ensure effective water infiltration and storage in the soil (Lal, 1997). The combined effect of capturing water and allowing for the infiltration of surface runoff makes the half-moon technique the most effective method for improv-
Table 1. Percentage of soil water content (average over all depths) according to site and technique

\begin{tabular}{lcc}
\hline \multirow{2}{*}{ Technique } & \multicolumn{2}{c}{ Site } \\
\cline { 2 - 3 } & $\begin{array}{c}\text { Dangadé } \\
\text { (Sahelian zone) }\end{array}$ & $\begin{array}{c}\text { Namoungou } \\
\text { (Sudanian zone) }\end{array}$ \\
\hline Half-moon & $4.69 \pm 0.96^{\mathrm{b}}$ & $10.45 \pm 2.39^{\mathrm{a}}$ \\
Zaï & $0.6 \pm 0.60^{\mathrm{c}}$ & $1.52 \pm 1.49^{\mathrm{c}}$ \\
Standard plantation & $0.82 \pm 0.67^{\mathrm{c}}$ & $7.4 \pm 1.54^{\mathrm{b}}$ \\
Average & $2.04 \pm 2.06$ & $6.46 \pm 4.2$
\end{tabular}

Note: means followed by the same letter are not statistically different at $p=0.05$ tested by Tukey's test.

ing SWC on degraded soils (Kagambèga et al., 2011a). Soil moisture is vital to the success of revegetation programmes (Banerjee, 1990), because soil moisture plays an important role in promoting root growth of plant seedlings ( $\mathrm{Li}$ and Chen, 1995). In our study, the pits of zaii and standard plantation collected the surface runoff water, but both had a smaller surface area compared to half-moons. This could explain the low SWC and the high and speedy mortality rates of J. curcas when we used these techniques.

SWC also varied significantly between the study sites (df $=1 ; F=73.48 ; p=0.00)$. SWC depends on precipitation rate, and the precipitation was significantly higher in Namoungou, in the Sudanian zone, than in Dangadé, which is located in the Sahel (Table 1). 
Table 2. Summary of the results of the two-way ANOVA investigating the effects of site and treatment on the survival and growth of $J$. curcas seedlings

\begin{tabular}{lrrr|rrr|rrr}
\hline & \multicolumn{3}{c}{ Survival rate } & \multicolumn{3}{c|}{ Diameter } & \multicolumn{3}{c}{ Height } \\
\cline { 2 - 10 } Sources of variation & df & $F$ & $p$ & df & $F$ & $p$ & df & $F$ & $p$ \\
\hline Site & 1 & 9.74 & 0.0033 & 1 & 133.40 & $<0.0001$ & 1 & 82.61 & $<0.0001$ \\
Treatment & 2 & 8.91 & 0.0006 & 2 & 27.78 & $<0.0001$ & 2 & 18.54 & $<0.0001$ \\
Site treatment & 2 & 2.18 & 0.1247 & 2 & 7.78 & 0.0004 & 2 & 13.74 & $<0.0001$ \\
\hline
\end{tabular}

Note: df: degree of freedom; $F$ : Fisher value; $p$ : significance level
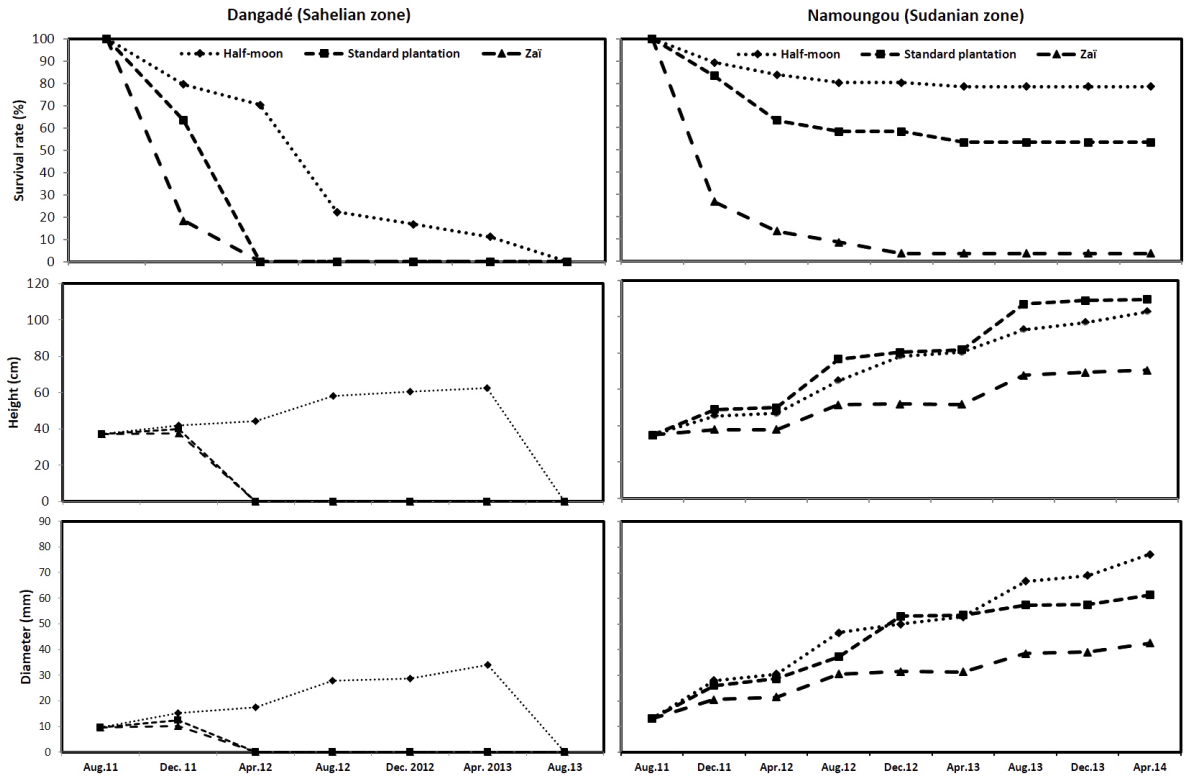

Figure 5. Survival rate and mean growth of seedlings.

Improvement of soil water using appropriate waterharvesting techniques is the main condition favoring degraded land rehabilitation. The techniques used in our study (half-moon, zaï and standard plantation) modify the physical characteristics of the soil and increase the infiltration and storage of runoff water (Kagambèga et al., 2011b).

\subsection{Effect of treatment on survival rate and seedling growth}

Overall, over 33 months the survival rates of the seedlings were $78.57 \%$ in the half-moon treatment and $0 \%$ in the zaï treatment (Fig. 5). Most of seedlings died in the first 9 months after planting. Seedling growth varied significantly between treatments, study sites and interaction between study sites and treatments (Table 2).

$J$. curcas seedlings showed significantly higher growth and survival rates under the half-moon at both sites than under the two other treatments. It is noteworthy that all of the plants in the Sahel zone, independently of treatment, perished, at the latest, 2 years after they were planted. At Namoungou (north
Sudanian zone), the survival rate was overall higher than at Dangadé (Sahelian zone). Overall, J. curcas seedlings were found to profit more from the effects of the half-moon and standard plantation techniques in the north Sudanian zone. The poor survival rates for seedlings under all of the techniques in the Sahelian zone may be an indication that J. curcas is barely able to survive at all on barren areas receiving very low rainfall. Our results corroborate those of Kun et al. (2007), who reported low survival and reproductive rates of $J$. curcas in barren areas in Yunnan Province, southwest China. The results of our study indicate that the limited water supply in the Sahelian zone may be responsible for the poor performance of $J$. curcas seedlings in all of the restoration techniques tested.

It is important to stress that the seeds of $J$. curcas used for this study were collected in Fada N'gourma and Pama, situated in the Sudanian area and receiving a better rainfall regime than in the Sahel. The effect of seeds' provenance on the outcome of the study in Dagandé is therefore unclear. It is not to exclude that other genotypes from the Sahel, more 
adapted to dryer conditions, may have led to different results. This aspect needs to be investigated further in future studies.

The high survival rate obtained for the half-moon technique at the Namoungou site demonstrate that this technique is suitable for increasing and maintaining soil water content over extended periods of time. Figure 3 shows that most of the seedlings died principally during the April-May period, which corresponds to the peak of the dry season in the Sahel. This is an indication that $J$. curcas may not be as drought-resistant as is commonly claimed in the abundant literature that praises this so-called "wonder plant" (Fairless, 2007). In the Sudanian zone, $78 \%$ of seedlings survived from August 2011 to April 2014 under the half-moon treatment, confirming the capability of this technology to improve soil properties and thus plant productivity.

\section{Conclusions}

The aim of this experiment was to study the effects of three soil and water conservation techniques on the growth parameters and survival rate of $J$. curcas at two denuded sites in Burkina Faso. After 33 months of experimentation, all plants died in the Sahel, while $70 \%$ of seedlings survived under half-moon treatment in the Sudanian zone, where soil water content was higher. Furthermore, our results showed that most of the plants died in the Sahel between April and May, which is the peak of the dry season, therefore suggesting that $J$. curcas may not be as drought-resistant as suggested by the very prolific literature praising the productivity of this plant. In the Sahel, the mortality of all of seedlings under all of the treatments, 2 years after establishment of the plantations, calls into question the ability of J. curcas to thrive in arid environments as claimed in the literature; it therefore may not be suitable for restoration/rehabilitation of degraded lands in the Sahel of Burkina Faso.

Author contributions. P. Bayen conducted the study, compiled the data, conceived the ideas of this manuscript, conducted the analysis and submitted the first draft; T. K. Sop deepened the ideas of the paper, provided guidance for data analysis and contributed to the writing.

A. Thiombiano and A. M. Lykke initiated the project UNDESERT, scientifically supervised the implementation of the research and data collection and provided comments on the manuscript.
Acknowledgements. The authors acknowledge the financial support of UNDESERT - Understanding and Combating Desertification to Mitigate its Impact on Ecosystem Services (EU-FP7 no. 243906). We thank our field assistants for their hard work continuously monitoring the plantations. We are grateful to Cleve Hick for proof-checking the English of this manuscript.

Edited by: A. Cerdà

\section{References}

Achten, W. M. J., Verchot, L., Franken, Y. J., Mathijs, E., Singh, V. P., Aerts, R., and Muys, B.: Jatropha bio-diesel production and use, Biomass Bioenerg., 32, 1063-1084, 2008.

Achten, W. M. J., Maes, W. H., Reubens, B., Mathijs, E., Singh, V. P., Verchot, L., and Muys, B.: Biomass production and allocation in Jatropha curcas L. seedlings under different levels of drought stress, Biomass Bioenerg., 34, 667-676, 2010a.

Achten, W. M. J., Maes, W. H., Aerts, R., Verchot, L., Trabucco, A., Mathijs, E., Singh, V. P., and Muys B.: Jatropha: from global hype to local opportunity, J. Arid Environ., 74, 164-165, 2010 b.

Banerjee, A. K.: Revegetation Technologies, in: Watershed development in Asia: strategies and technologies, World Bank Technical Paper No. 127, World Bank: Washington, DC, USA, 109-129, 1990.

Barua, S. K., and Haque S. M. S.: Soil characteristics and carbon sequestration potentials of vegetation in degraded hills of chittagong, Bangladesh, Land Degrad. Develop., 24, 63-71, 2013.

Baumert, S., Khamzina, A., and Vlek, P. L. G.: Soil organic carbon sequestration in Jatropha curcas L. systems in Burkina Faso, Land Degrad. Develop., doi:10.1002/ldr.2310, onine first, 2014.

Bayen, P., Traoré, S., Bognounou, F., Kaiser, D., and Thiombiano, A.: Effet du zaï amélioré sur la productivité du sorgho en zone sahélienne, VertigO - la revue électronique en sciences de l'environnement, Volume 11 Numéro 3, 2011.

Bayen, P., Bognounou, F., Lykke, A. M., Ouédraogo, M., and Thiombiano, A.: The use of biomass production and allometric models to estimate carbon sequestration of Jatropha curcas L. plantations in western Burkina Faso, Environ. Dev. Sustain., Springer Science+Business Media, Dordrecht, the Netherlands, doi:10.1007/s10668-015-9631-4, 2015.

Bisaro, A., Kirk, M., Zdruli, P., and Zimmermann, W.: Global drivers setting desertification research priorities: insights from a stakeholder consultation forum, Land Degrad. Develop., 25, 516, 2014.

Casenave, A., and Valentin, C.: A runoff capability classification system based on surface features criteria in the arid and semiarid areas of West Africa, J. Hydrol., 130, 231-249, 1992.

Cerda, A., Schnabel, S., Ceballos, A., and Gomez-Amelia, D.: Soil hydrological response under simulated rainfall in the Dehesa land system (Extremadura, SW Spain) under drought conditions, Earth Surf. Proc. Land., 23, 195-209, 1998.

Fairless, D.: Biofuel: the little shrub that could maybe, Nature, 449, 652-655, 2007.

Fisher, R. F.: Amelioration of degraded rain forest soils by plantations of native trees, Soil Sci. Soc. Am. J., 59, 544-549, 1995. 
Fleskens, L. and Stringer, L. C.: Land management and policy responses to mitigate desertification and land degradation, Land Degrad. Develop., 25, 1-4, doi:10.1002/ldr.2272, 2014.

Ganaba, S.: Impact des aménagements de conservation des eaux et des sols sur la régénération des ressources ligneuses en zone sahélienne et nord soudanienne du Burkina Faso, Vertigo, 6, 126-140, 2005.

Gilardelli, F., Sgorbati, S., Citterio, S., and Gentili, R.: Restoring limestone quarries: hayseed, commercial seed mixture or spontaneous succession?, Land Degrad. Develop., doi:10.1002/ldr.2244, online first, 2013.

Kagambèga, F. W., Traoré, S., Thiombiano, A., and Boussim, I. J.: Impact de trois techniques de restauration des sols sur la survie et la croissance de trois espèces ligneuses sur les "zipellés" au Burkina Faso, Int. J. Biol. Chem. Sci., 5, 901-914, 2011 a.

Kagambèga, W. F., Thiombiano, A., Traoré, S., Zougmoré, R., and Boussim, J. I.: Survival and growth responses of Jatropha curcas L. to three restoration techniques on degraded soils in Burkina Faso, Ann. For. Res., 54, 171-184, 2011 b.

Kun, L., Wen-yun, Y., Li, L., Chun-hua, Z., Yong-zhong, C., and Yong-yu, S.: Distribution and development strategy for Jatropha curcas L. in Yunnan Province, Southwest China, For. Stud. China, 9, 120-126, 2007.

Lal, R.: Soil quality and sustainability, in: Methods for assessment of soil degradation, edited by: Lal, R., Blum, W. H., Valentin, C., and Stewart, B. A., CRC Press, Boca Raton, New York, 17-31, 1997.

Li, K. and Chen, Y.: Studies on water input and soil moisture of artificial forested land in Yuanmou, region of the dry and hot valley, For. Res., 8, 651-657, 1995.

Maes, W. H., Trabucco, A., Achten, W. M. J., and Muys, B.: Climatic growing conditions of Jatropha curcas L., Biomass Bioenerg., 33, 1481-1485, 2009.

Mando, A., Brussaard, L., and Stroosnijder, L.: Termite-and-mulch mediated rehabilitation of crusted Sahel vegetation, Restor. Ecol., 7, 33-41, 1999.

Martínez-Garza, C., Tobon, W., Campo, J., and Howe, H. F.: Drought mortality of tree seedlings in an eroded tropical pasture, Land Degrad. Develop., 24, 287-295, 2013.
Meng, Y. Caiyan, L. George, F., and Harinder, P. S. M.: Current situation and prospects of Jatropha curcas as a multipurpose tree in China, Agroforest Syst., 76, 487-497, 2009.

Parrotta, J.: The role of plantation forests in rehabilitating degraded tropical ecosystems, Agric. Ecosyst. Environ., 41, 115133, 1992.

Rao, A. V. R. K., Wani, P. S., Singh, P., Srinivas, K., and Srinivasa, R. Ch.: Water requirement and use by Jatropha curcas L. in a semi-arid tropical location, Biomass Bioenerg., 39, 175-181, 2012.

Roose, E., Kaboré, V., and Guenat, C.: Zaï practice: a West African traditional rehabilitation system for semiarid degraded lands, a case study in Burkina Faso, Arid Soil Res. Rehab., 13, 343-355, 1999.

SAS Institute, Inc.: JMP 9 Discovering JMP, Cary, NC, États-Unis, SAS Institute, 148, 2010.

Sidibé, A.: Farm-level adoption of soil and water conservation techniques in northern Burkina Faso, Agric. Water Manage., 71, 211 224, 2005.

Sop, T. K., Bellefontaine, R., Thiombiano, A., Kagambèga, F. W., and Schmiede, U.: Effects of organic amendment on early growth performance of Jatropha curcas L. on a severely degraded site in the Sub-Sahel of Burkina Faso, Agroforest. Syst., 86, 387-399, 2012.

Zougmoré, R., Zida, Z., and Kambou, N. F.: Role of nutrient amendments in the success of half-moon, soil and water conservation practice in semiarid Burkina Faso, Soil Till. Res., 71, 143-149, 2003.

Zucca, C., Bautista, S., Orr, B. J., and Previtali, F.: Desertification: prevention and restoration, in: Encyclopedia of environmental management, Vol. I, edited by: Jorgensen, S. E., Taylor \& Francis, New York, USA, 594-609, doi:10.1081/E-EEM-120046343, 2013.

Zucca, C., Wu, W., Dessena, L., and Mulas, M.: Assessing the effectiveness of land restoration interventions in dry lands by multitemporal remote sensing - a case study in ouled dlim (Marrakech, Morocco), Land Degrad. Develop., doi:10.1002/ldr.2307, 2014. 